\title{
FACTORS AFFECTING INTERNATIONAL VISITORS' PREFERENCE FOR LOCAL FRUITS IN THE MEKONG DELTA, VIETNAM
}

\author{
Nguyen Quoc Nghi \\ Can Tho University, \\ Mekong Delta, \\ Vietnam
}

\author{
Bui Thi Yen Ni \\ Can Tho Lottery Company, \\ Mekong Delta, \\ Vietnam
}

Article DOI: https://doi.org/10.36713/epra4910

\begin{abstract}
The objective of this study is to identify the factors affecting the taste of specialty fruits in the Mekong Delta of international visitors. The quota sampling method was used to interview 180 international visitors who have visited fruit orchards and enjoyed specialty fruits in the Mekong Delta. Applying the linear regression with the study has identified 4 factors affecting the preference for fruit specialties in the Mekong Delta of international tourists, namely "Culinary culture", "Information and experience", "Product features", and "Perceived value". In particular, the factor "Information and experience" most strongly influences international visitors' preference for fruit specialties in the Mekong Delta.
\end{abstract}

KEYWORDS: Preference, specialties, fruit, Mekong Delta

\section{INTRODUCTION}

The Mekong Delta owns about 300.000 ha of fruit orchards (accounting for $37.5 \%$ of the country's total fruit plantation area). The total output is about 3.8 million tons/year, accounting for over $70 \%$ of the total production over the country. The Mekong Delta locates in the lower Mekong River with interlace river systems. With the favorable climatic conditions and a considerable amount of alluvial from the Mekong River, the Mekong Delta has become the most generous fruit bowl in Vietnam. There are plenty of specialty fruits such as Hoa Loc mango in Tien Giang Province, Lai Vung tangerine in Dong Thap Province, and green-skin grapefruit in Ben Tre Province, etc. Many fruit orchards in the Mekong Delta are famous for both domestic and oversea tourists such as Cai Be and Vinh Kim (Tien Giang Province), Cai Mon (Ben Tre Province), An Binh islet (Vinh Long Province), and My Khanh (Can Tho City). Farmers in the Mekong Delta have combined fruit orchards with the eco-tourism to diversify income sources and promote fruit specialties for domestic and foreign tourists. With the above advantages, the Mekong Delta is a favorite destination for international travelers in the journey to explore the ecological environment and experience unique cultures. To further clarify the attractiveness of local fruit to international tourists, this study was conducted to find out factors that influence the preference for specialty fruit in the Mekong Delta of international visitors.

\section{LITERATURE REVIEW}

There have been numerous studies proving the role of cuisine in tourism development, especially the attraction of culinary specialties for tourists. Studies by Mak et al. (2012), Chang et al. (2011), Atkins \& Bowler (2001) suggested that culture is an essential factor influencing visitors' eating behaviors. Culture and religion affect the ability to consume food of visitors. According to Yurtseven \& Kaya (2011), visitors spend new types of cuisine because they have the opportunity to expand their knowledge and understanding of the culture of different regions. Kim \& Scarles (2009) and Mak et al. (2012) argued that the attraction of culinary specialties could stimulate visitors to buy more products, and the characteristics of things are decisive factors. As reported by Mak et al. (2012), Yurtseven \& Kaya (2011), Kim \& Scarles (2009), the culinary experience influences the ability to consume food during the trip. Besides, Yurtseven \& Kaya (2011) and Chang et al. (2011) said that product quality is an essential factor affecting the consumption of local cuisine of visitors. Research by Chang et al. $(2010,2011)$ has shown that the product price has a particular impact on tourists' culinary consumption behavior.

Based on the literature review, the study used a group discussion (qualitative research) with 6 international visitors who have enjoyed specialty fruits in the Mekong Delta. The results of the group discussion set out the research hypotheses and appropriate scales for the research model. Specifically, research hypotheses are proposed as follows: H1: Culinary culture positively influences the preference for the Mekong Delta specialty fruits of international tourists. H2: Information and experience positively 
impact the choice for specialty fruits in the Mekong Delta of international tourists. H3: Product features positively affects the preference for the Mekong Delta specialty fruits of international tourists. H4: Perceived value positively influences the taste for specialty fruits in the Mekong Delta of international tourists. Hence, the research model is stated as follow:

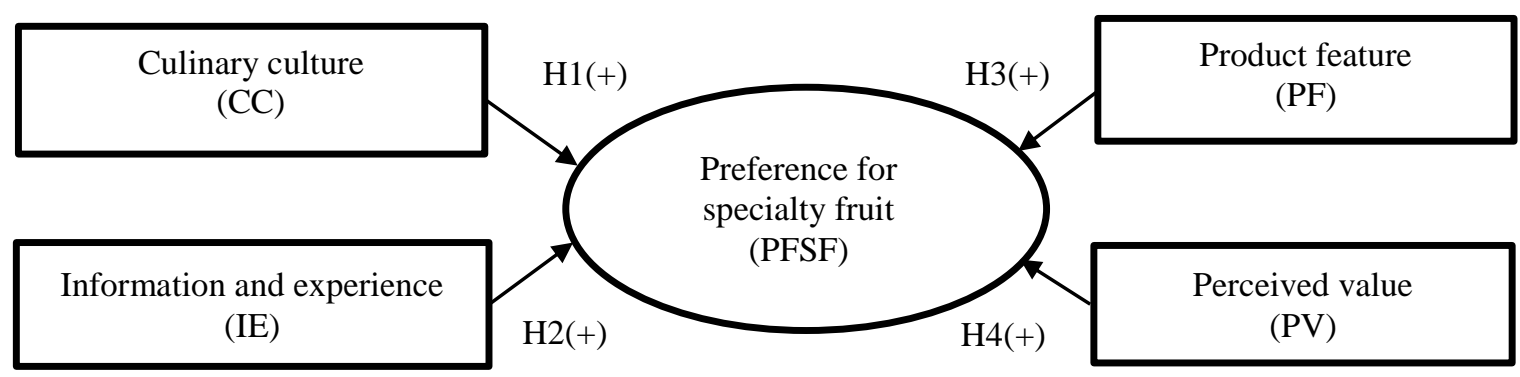

Figure 1: Proposed research model

Table 1

Interpretation of observed variables in the research model

\begin{tabular}{|c|c|c|c|c|}
\hline Factor & Sign & Observed variables & $\begin{array}{l}\text { Reference } \\
\text { resources }\end{array}$ & Scale \\
\hline \multirow{4}{*}{$\begin{array}{l}\text { Preference } \\
\text { for specialty } \\
\text { fruit (PFSF) }\end{array}$} & PFSF1 & $\begin{array}{l}\text { Enjoying specialty fruits in the Mekong Delta is an } \\
\text { exciting experience. }\end{array}$ & \multirow{4}{*}{$\begin{array}{c}\text { Hassan \& Hall } \\
\text { (2003), Kim et al. } \\
\text { (2009), Yurtseven } \\
\text { \& Kaya (2011), } \\
\text { Duttagupta et al. } \\
\text { (2013) }\end{array}$} & \multirow{4}{*}{$\begin{array}{l}\text { Liker } \\
\text { t } 1-5\end{array}$} \\
\hline & PFSF2 & $\begin{array}{l}\text { I am excited when enjoying specialty fruits in the } \\
\text { Mekong Delta. }\end{array}$ & & \\
\hline & PFSF3 & $\begin{array}{l}\text { I want to enjoy more specialty fruits in the Mekong } \\
\text { Delta. }\end{array}$ & & \\
\hline & PFSF4 & $\begin{array}{l}\text { I would recommend Mekong Delta specialty fruits } \\
\text { to my relatives and friends. }\end{array}$ & & \\
\hline \multirow{4}{*}{$\begin{array}{l}\text { Culinary } \\
\text { culture (CC) }\end{array}$} & CC1 & $\begin{array}{l}\text { My culinary culture is consistent with the specialty } \\
\text { fruits of the Mekong Delta. }\end{array}$ & \multirow{4}{*}{$\begin{array}{l}\text { Atkins and Bowler } \\
\text { (2001), Kim et al. } \\
\text { (2009), Chang et } \\
\text { al. (2011), } \\
\text { Yurtseven \& Kaya } \\
\text { (2011), Mak et al. } \\
\text { (2012) }\end{array}$} & \multirow{4}{*}{$\begin{array}{l}\text { Liker } \\
\text { t } 1-5\end{array}$} \\
\hline & $\mathrm{CC} 2$ & $\begin{array}{l}\text { The culinary culture of the Mekong Delta people is } \\
\text { fascinating. }\end{array}$ & & \\
\hline & CC3 & $\begin{array}{l}\text { I enjoy the specialty fruits of the Mekong Delta to } \\
\text { expand my knowledge. }\end{array}$ & & \\
\hline & $\mathrm{CC} 4$ & $\begin{array}{l}\text { Specialty fruits in the Mekong Delta follow culinary } \\
\text { diversity. }\end{array}$ & & \\
\hline \multirow{4}{*}{$\begin{array}{c}\text { Information } \\
\text { and } \\
\text { experience } \\
\text { (IE) }\end{array}$} & IE1 & $\begin{array}{l}\text { There are many communication channels on the } \\
\text { specialty fruits of the Mekong Delta. }\end{array}$ & \multirow{4}{*}{$\begin{array}{l}\text { Kim et al. (2009), } \\
\text { Yurtseven \& Kaya } \\
\text { (2011), Chang et } \\
\text { al. (2011), Mak et } \\
\text { al. (2012), } \\
\text { Duttagupta (2013) }\end{array}$} & \multirow{4}{*}{$\begin{array}{l}\text { Liker } \\
\text { t } 1-5\end{array}$} \\
\hline & IE2 & $\begin{array}{l}\text { My friends and relatives introduced me specialty } \\
\text { fruits of the Mekong Delta. }\end{array}$ & & \\
\hline & IE3 & $\begin{array}{l}\text { I have experience in specialty fruits in the Mekong } \\
\text { Delta. }\end{array}$ & & \\
\hline & IE4 & I get used to consuming the Mekong Delta's fruits. & & \\
\hline \multirow{4}{*}{$\begin{array}{c}\text { Product } \\
\text { feature (PF) }\end{array}$} & PF1 & $\begin{array}{l}\text { Types and grades of specialty fruits in the Mekong } \\
\text { Delta are diverse. }\end{array}$ & \multirow{4}{*}{$\begin{array}{l}\text { Kim et al. (2009); } \\
\text { Yurtseven \& Kaya } \\
\text { (2011), Chang et } \\
\text { al. (2011); Mak et } \\
\text { al. (2012); }\end{array}$} & \multirow{4}{*}{$\begin{array}{l}\text { Liker } \\
\text { t } 1-5\end{array}$} \\
\hline & PF2 & $\begin{array}{l}\text { The shape and color of specialty fruits in the } \\
\text { Mekong Delta are eye-catching. }\end{array}$ & & \\
\hline & PF3 & $\begin{array}{l}\text { The quality of specialty fruits in the Mekong Delta is } \\
\text { always ensured. }\end{array}$ & & \\
\hline & PF4 & Specialty fruits' brands in the Mekong Delta are & & \\
\hline
\end{tabular}


EPRA International Journal of Multidisciplinary Research (IJMR) - Peer Reviewed Journal

Volume: 6 | Issue: 8 | August 2020 || Journal DOI: 10.36713/epra2013 || SJIF Impact Factor: 7.032 ||ISI Value: 1.188

\begin{tabular}{|c|c|c|c|c|}
\hline Factor & Sign & Observed variables & $\begin{array}{l}\text { Reference } \\
\text { resources }\end{array}$ & Scale \\
\hline & & reputable. & & \\
\hline \multirow{3}{*}{$\begin{array}{l}\text { Perceived } \\
\text { value (PV) }\end{array}$} & PV1 & $\begin{array}{l}\text { The price is always consistent with the quality of } \\
\text { Mekong Delta specialty fruits. }\end{array}$ & \multirow{3}{*}{$\begin{array}{l}\text { Kim et al. (2009), } \\
\text { Chang et al. (2010, } \\
\text { 2011), Yurtseven } \\
\text { \& Kaya (2011); }\end{array}$} & \multirow{3}{*}{$\begin{array}{l}\text { Liker } \\
\text { t } 1-5\end{array}$} \\
\hline & PV2 & $\begin{array}{l}\text { The price of Mekong Delta specialty fruits is } \\
\text { affordable. }\end{array}$ & & \\
\hline & PV3 & $\begin{array}{l}\text { With the cost, I and satisfied with the specialty } \\
\text { fruits of the Mekong Delta. }\end{array}$ & & \\
\hline
\end{tabular}

Source: Author's synthesis, 2019

\section{RESEARCH METHODOLOGY}

In this study, quantitative methods were used follow these steps, (1) Use the Cronbach's Alpha to test the internal correlation among observed variables; (2) Use the exploratory factor analysis (EFA) asses the convergent and discriminant validity of observed variables; (3) Use the linear regression to test the research hypotheses. The scales used in the model are in the form of a 5-level Likert scale with the choice range from level $1=$ strongly disagree, and level $5=$ strongly agree.

The quota sampling was applied to survey 180 international visitors who have visited the Mekong Delta and enjoyed specialty fruits. During the survey, demographic criteria were used to group the survey subjects. According to Hair et al. (1998), the exploratory factor analysis (EFA) requires the proportion of observations/the measurement variable is 5:1, meaning that a measurement variable needs a minimum of 5 statements. Tabachnick et al. (2007) pointed out that the appropriate sample size for regression analysis is $\mathrm{N} \geq 50+5^{*} \mathrm{~m}$ (where $\mathrm{m}$ is the number of independent variables). Thus, the sample size meets the reliability requirement for testing hypotheses.

\section{RESEARCH RESULTS AND DISCUSSIONS}

4.1 Evaluate the reliability of scales

Cronbach's Alpha test

The rankings are assessed for reliability through Cronbach's Alpha coefficient. Cronbach's Alpha is used to eliminate variables with "garbage" values and those with a corrected item-total correlation of less than 0.3 (Nunnally, 1978; Peterson, 1994; Slater, 1995). A scale is chosen if its Cronbach's Alpha value is greater than 0.6 (Nunnally $\&$ Bernstein, 1994). According to the result in Table 2 , the scales (preference for specialty fruits, culinary culture, information and experience, product features, perceived value) have high reliability $(\alpha \geq$ 0.7 ). The corrected item-total correlation values of all observed variables are more generous than 0.3. Therefore, it is suggested that the scales proposed in the research model are reliable.

Table 2

Scale reliability test result

\begin{tabular}{lrrr}
\hline Factor & $\begin{array}{r}\text { Cronbach's Alpha } \\
\text { Minimum item-total } \\
\text { correlation }\end{array}$ & $\begin{array}{r}\text { Cronbach's Alpha } \\
\text { if item deleted }\end{array}$ \\
\hline Preference for specialty fruit & 0.865 & 0.678 & 0.829 \\
Culinary culture & 0.783 & 0.570 & 0.740 \\
Information and experience & 0.811 & 0.580 & 0.786 \\
Product feature & 0.842 & 0.664 & 0.805 \\
Perceived value & 0.828 & 0.651 & 0.798 \\
\hline
\end{tabular}

Source: Survey data, 2019

\section{Exploratory factor analysis (EFA)}

According to the EFA result for the independent variables (culinary culture, information and experience, product feature, and perceived value), the indicators are ensured as follows: Significance level of the model (Sig) is less than 0.05 and the KMO value $=0.85$ (in the range of 0 and 1). The factor loading values of all observed variables are greater than 0.5 . The average variance extracted is $67.58 \%>50 \%$. This shows that the research data is satisfactory (Anderson and Gerbing, 1988). The analytical result creates 4 factors, and the observations belong to factors as in the proposed model, so there is no change in the factors' names. Similarly, the EFA result for the dependent variable (preference for specialty fruit) is satisfactory. The significance level (Sig) is less than 0.05 , and the $\mathrm{KMO}=0.82$ (between 0 and 1 ). The factor loading values of all observed variables are greater than 0.5 . The 
average variance extracted is $71.32 \%>50 \%$. This implies that the research data is satisfactory (Anderson and Gerbing, 1988). Thus, the result forms 1 factor with the unchanged observations. All factors are summarized in the table below.

Table 3

Summary of factors formed from the exploratory factor analysis

\begin{tabular}{cll}
\hline Sign & observed variable & Factor \\
\hline CC & 4 variables: CC1, CC2, CC3, CC4 & Culinary culture \\
IE & 4 variables: IE1, IE2, IE3, IE4 & Information and experience \\
PF & 4 variables: PF1, PF2, PF3, PF4 & Product feature \\
PV & 3 variables: PV1, PV2, PV3 & Perceived value \\
PFSF & 4 variables: PFSF1, PFSF2, PFSF3, PFSF4 & Preference for specialty fruit \\
\hline Source: Survey data, 2019 &
\end{tabular}

\subsection{Linear regression}

The linear regression is used to test the research hypotheses. The testing result is shown in Table 4.

Table 4

Hypotheses test result

\begin{tabular}{lrrrr}
\hline Factor & $\begin{array}{r}\text { Standardized } \\
\text { coefficient }\end{array}$ & $\begin{array}{r}\text { Significance } \\
\text { level (Sig.) }\end{array}$ & $\begin{array}{r}\text { Variance inflation } \\
\text { factor VIF }\end{array}$ & Hypothesis \\
\hline Culinary culture & 0.155 & 0.014 & 1.639 & H1: accepted \\
Information and experience & 0.310 & 0.000 & 1.832 & H2: accepted \\
Product feature & 0.245 & 0.000 & 1.734 & H3: accepted \\
Perceived value & 0.240 & 0.000 & 1.631 & H6: accepted \\
\hline Adjusted R & & & 0.573 \\
Durbin - Watson coefficient & & & 1.936 \\
Sig.F & & & 0.000 \\
\hline
\end{tabular}

Source: Survey data, 2019

Based on Table 4, the adjusted R2 value is $57.3 \%$ which proves that factors explain the preference for specialty fruit in the Mekong Delta of international tourists at a high level. The Sig.F $=0.00$, showing that the research model is statistically significant. Durbin-Watson $=1.936$ and VIF $<4$, this indicates that there is no autocorrelation and multicollinearity. Besides, the independent variables in the model are statistically significant at the $95 \%$ level, which means culinary culture, information and experience, product feature, and perceived value influence oversea visitors' interest in specialty fruits in the Mekong Delta. In other words, specialty fruits in the Mekong Delta are accordance with the culinary culture of most international tourists. Communication channels providing certain information on specialty fruits in the Mekong Delta influence the interest of international tourists. The various types and quality assurance have created a prestigious brand of the Mekong Delta fruits among international tourists. In addition to this, the pricing which is consistent with the product quality and affordability of tourists that has improved international tourists' preference for specialty fruits in the Mekong Delta.

\section{CONCLUSION}

Overall, the study has demonstrated 4 factors that positively influence the preference for specialty fruits in the Mekong Delta of international tourists. They are culinary culture, information and experience, product feature, and perceived value. In which, the "information and experience" factor has the most decisive influence on the preference for specialty fruits in the Mekong Delta of international visitors. Based on the above results, some policy implications are proposed. Firstly, develop and implement a professional communication strategy to promote the image of the Mekong Delta's specialty fruits. Secondly, improve the quality of specialty fruits to meet international tourists' demands. Thirdly, strictly manage the pricing for specialty fruits, ensuring that they are in line with the willingness to pay of international travelers.

\section{REFERENCES}

1. Anderson, J. C., \& Gerbing, D. W. (1988). Structural equation modeling in practice: $A$ review and recommended two-step approach. Psychological Bulletin, 103(3), 411-423.

2. Atkins, P., \& Bowler, I. (2001). Food in Society: Economy. Culture and Geography. London: Arnold. 
3. Chang, R. C., Kivela, J., \& Mak, A. H. (2010). Food preferences of Chinese tourists. Annals of tourism research, 37(4), 989-1011.

4. Chang, R. C., Kivela, J., \& Mak, A. H. (2011). Attributes that influence the evaluation of travel dining experience: When East meets West. Tourism Management, 32(2), 307-316.

5. Duttagupta, S. (2013). Foreign travelers' recommendation of culinary tourism in India based on cuisine image and satisfaction with experiences at culinary establishments: an exploratory study. Master's thesis. University of Waterloo.

6. Hair, J. F., Tatham, R. L., Anderson, R. E., \& Black, W. C. (1998). Multivariate Data Analysis (5th ed.). New Jersey: Prentice-Hall.

7. Hassan, M. W., \& Hall, C. M. (2003). The demand for halal food among Muslim travelers in New Zealand. In C. M. Hall, L. Sharples, R. Mitchell, B. Cambourne, and N. Macionis (Ed.). Food tourism around the world: Development, Management, and Markets (pp. 81-101). Oxford: ButterworthHeinemann.

8. Kim, Y. G., Eves, A., \& Scarles, C. (2009). Building a model of local food consumption on trips and holidays: A grounded theory approach. International journal of hospitality management, 28(3), 423-431.

9. Mak, A. H., Lumbers, M., Eves, A., \& Chang, R. C. (2012). Factors influencing tourist food consumption. International Journal of Hospitality Management, 31(3), 928-936.

10. Nunnally, J. (1978). Psychometric Theory. New York: McGraw-Hill.

11. Nunnally, J. C., \& Bernstein, I. H. (1994). Psychometric theory (3rd ed.). New York: McGrawHill.

12. Peterson, R. (1994). A Meta-Analysis of Cronbach's Coefficient Alpha. Journal of Consumer Research, 21(2), 381-391.

13. Slater, S. (1995). Issues in Conducting Marketing Strategy Research. Journal of Strategic, 3(4), 257270.

14. Tabachnick, B. G., Fidell, L. S., \& Ullman, J. B. (2007). Using multivariate statistics (Vol. 5). Boston, MA: Pearson

15. Yurtseven, H. R., \& Kaya, O. (2011). Local Food In Local Menus: The Case Of Gokceada. TOURISM'S: An International Multidisciplinary Journal of Tourism, 6(2), 263-275. 